\title{
Strategic Management Accounting and Firm Performance: Evidence from Finance Businesses in Thailand
}

\author{
Kornchai PHORNLAPHATRACHAKORN ${ }^{1}$, Khajit NA-KALASINDHU ${ }^{2}$
}

Received: June 03, 2020 Revised: June 28, 2020 Accepted: July 09, 2020

\begin{abstract}
This study aims to examine the effects of strategic management accounting on firm performance of finance businesses in Thailand. Strategic management accounting comprises of environmental scanning, competitor orientation and forward-looking information. In this study, 175 finance businesses in Thailand are the samples of the study. A mail survey procedure was used for data collection. The hierarchical multiple regression analysis is employed to test the research relationships. Firstly, environmental scanning positively affects operational excellence, organizational effectiveness and firm performance. Secondly, competitor orientation is positively related to managerial efficiency and organizational effectiveness. Thirdly, forward-looking information has a positive influence on operational excellence, managerial efficiency, organizational effectiveness, and firm performance. In addition, operational excellence, managerial efficiency and organizational effectiveness have positive impact on firm performance. Finally, to verify the mediating effects, operational excellence, managerial efficiency and organizational effectiveness are the mediators of the research relationships. This study confirms that all dimensions of strategic management accounting play a significant role in determining business outcome as being congruent with the theory of resourcebased views of the firms. Executives of firms need to provide valuable resources and capabilities to support the strategic management accounting implementation in order to achieve good business outcome in highly competitive environments.
\end{abstract}

Keywords: Strategic Management Accounting, Environmental Scanning, Competitor Orientation, Forward-looking Information, Firm Performance

JEL Classification Code: M41

\section{Introduction}

Nowadays, business environments have dramatically changed in several aspects, including establishing global operations, issuing intense laws and regulations, developing technological growth, requiring corporate social responsibility, and dealing with competitive complexity. For micro aspects, changing demand pattern, short product life

\footnotetext{
${ }^{1}$ First Author and Corresponding Author. Associate Professor, Institute for Business and Accounting Innovation, Nakhan Phanom University, Thailand [Postal Address: Nakhon Phanom, 48000, Thailand] Email: kornchai.p@npu.ac.th

${ }^{2}$ Assistant Professor, Institute for Business and Accounting Innovation, Nakhan Phanom University, Thailand.

Email: khajit.nk@npu.ac.th

(c) Copyright: The Author(s)

This is an Open Access article distributed under the terms of the Creative Commons Attribution Non-Commercial License (http://Creativecommons.org/licenses/by-nc/4.0/) which permits unrestricted noncommercial use, distribution, and reproduction in any medium, provided the original work is properly cited.
}

cycles, dynamic market, presence of multiple competitors and customer demand for customized products are the characteristics of business operations (Aaltola, 2019; Pasch, 2019). Accordingly, firms that need to survive and be sustainable under those business environments are required to respond to them well.

They have to deal with the environments and receive the practical results. Good information has become a key factor for driving firms' success, profitability, survival, and sustainability. In this study, strategic management accounting is a main tool that provides best supporting information for directing, planning, controlling, and decision-making activities in order to gain success for firms' business strategies and operation. Firms with best strategic management accounting tend to have excellent business practices, superior corporate competitiveness and valuable firm performance (Oboh \& Ajibolade, 2017). Thus, this study attempts to investigate the effects of strategic management accounting on firm performance. 
Strategic management accounting is defined as the provision and analysis of management accounting data about a business and its competition which can be used in the development and monitoring the strategy of its business, particularly relating levels and trends in real costs and prices, volume, market share, cash flow, and proportion demanded of a firm's total resources (Lachmann, Knauer, \& Trapp, 2013). It extensively focuses on providing information relevant to assessing its competitive position in an industry, with an emphasis on customers and competitors as externally located objects of management accounting analysis. Also, strategic management accounting refers to the provision of information that supports organization's decisions in the long run and a significant effect on organizational performance as it provides both internal as well as external information. It is a technique that emphasizes external as well as non-financial and internally generated information. Firms have utilized it as a common-sense approach to the problems emanating from a changing competitive and technological environment.

In the study of Cadez and Guilding (2008), strategic management accounting consists of strategic costing; planning, control and performance measurement; strategic decision-making; competitor accounting; and customer accounting. It is viewed as a set of strategically oriented management accounting techniques, considering the potential for greater management accounting engagement in the strategic management process and concerning with the involvement of accountants in corporate decision-making activities. Firms with applying strategic management accounting seem to focus on strategic types (prospectors, defenders, and analyzers), degree to which strategy is deliberately formulated and degree of market orientation (Cheng, Li, Lin, \& Chih, 2020). To achieve the research goal, this study implements strategic management accounting by emphasizing environmental scanning, competitor orientation and forward-looking information.

Under the increasingly dynamic environments, those strategic management accounting dimensions are employed to improve firm performance. Thus, the roles of environmental scanning, competitor orientation, and forward-looking information in explaining firm performance were empirically investigated. While previous studies have investigated the strategic management accounting-firm performance relationships, they have only focused on the overall of strategic management accounting. In this study, dimensions of strategic management accounting (environmental scanning, competitor orientation and forward-looking information) have been treated as the factors of determining strategic management accounting. Likewise, some studies have shown that strategic management accounting may not directly lead to firm performance, but it needs to have mediators that help link to firm performance. Accordingly, this study has proposed operational excellence, managerial efficiency and organizational effectiveness as the mediators of the study (Chang \& Ma, 2019; Sharma \& Singh, 2019).

In this study, firm performance is the consequence of the study and it is the potential outcome of doing businesses under the uncertain environments. In the existing literature, firm performance is measured in several aspects, such as return on equity, return on asset, earnings per share, and sale growth (Nguyen \& Nguyen, 2020) and balanced scorecard as financial and non-financial sectors (financial perspective, customer perspective, internal business process perspective, and learning and growth perspective (Truong, Nguyen, \& Duong, 2020). Here, this study focuses on the measurement of firm performance as the achievement of the goal and objective settings, the profitability and the market share of the business operations, the stakeholder acceptance from the organizational activities, and the executive satisfaction of the business outcomes (Joni, Ahmed, \& Hamilton, 2019).

In congruence with the resource-based view of the firm (Barney, 1991), internal resources are sources of competitive advantage and performance. In this study, strategic management accounting as one of firms' internal resources has an important impact on sustainable competitive advantage through operational excellence, managerial efficiency and organizational effectiveness and their performance. To verify the research relationships, finance businesses in Thailand are selected as the samples of the study because a few studies in previous research have paid attention on the Thai aspects. To increase the generalizability of the existing literature and confirm the results of these studies, the finance businesses in Thailand are appropriate in this study. Also, these businesses, namely banks, insurance, investment, security, and credit foncier companies and related businesses are large and complex organizations that have many various transactions, operations, activities, practices, and actions. They play significant roles in driving Thai economy. Thus, the empirical evidence from the financial businesses can enhance the benefits and advantages of themselves and the Thai economy. Hence, an effective strategic tool for helping them succeed, survive and sustain in the competitive markets and environments is needed. In this study, strategic management accounting is considered as a main source of their competitive advantage and performance. Therefore, strategic management accounting enables the businesses to operate effectively and succeed in highly complex environments. According to the research results, firms could clearly understand the importance and benefit of the strategic management accounting implementation and identify the outcomes of its implementation.

This study aims at examining the effects of strategic management accounting on firm performance of finance businesses in Thailand. The key research question in this study is how strategic management accounting has an impact on firm performance. The specific research questions are: 
(1) How environmental scanning, competitor orientation and forward-looking information affect operational excellence, managerial efficiency and organizational effectiveness and (2) How operational excellence, managerial efficiency and organizational effectiveness influence firm performance.

\section{Literature Review and Hypotheses}

Here, strategic management accounting is a valuable source of the firm's competitive advantage and performance according to the resource-based views of the firms (Barney, 2001). It is valuable, rare and not easily imitated and substitutable. Firms with successful strategic management accounting implementation are likely to have their great performance. Also, operational excellence, managerial efficiency and organizational effectiveness are the mediators of the study. Thus, the model presents the aforementioned relationships, as shown in Figure 1.

\subsection{Environmental Scanning}

Environmental scanning is defined as the collection and use of information about events, trends, changes, and relationships in a firm's external environments that assist management in planning its future course of actions and securing and improving its position in the future (Bhardwaj \& Kumar, 2014; Yu, Chavez, Jacobs, Yew Wong, \& Yuan, 2019). It is a process to understand, gather, analyze, dispense, and interpret external force information and use the results in the strategic planning process. Firms with environmental scanning are able to cope with uncertainties and improve their competitive position for achieving superior performance, survival and sustainability. Also, environmental scanning has valuable activities, including the gathering of information concerning a firm's external environments, the analysis and interpretation of this information and the use of this analyzed intelligence in strategic decision making (Abu-Rahma \& Jaleel, 2019). It explicitly generates information that enables top managements to move beyond reactive adaptation into a more proactive influencing of their environmental conditions.

Under the uncertain and complex environments, firms have monitored, evaluated and disseminated the external environments to identify opportunities and threats and to establish critical strategies for gaining competitive advantage and receiving business success in the competitive markets. In the accounting aspect, environmental scanning is the important function of strategic management accounting in the competitive situations. It becomes the design and use of particular instrument that associates with a firm' strategies employed for improving its performance via operational excellence, managerial efficiency and organizational effectiveness (Lachmann, Knauer, \& Trapp, 2013). Firms have a potential to scan business environments and provide and analyze management accounting data for use in developing and monitoring business strategy and achieving and sustaining competitive advantage and firm performance in the competitive marketplace. Hence, environmental scanning helps firms learn business environments, provide corporate competitiveness and gain great firm performance. Therefore,

H1: Environmental scanning positively affects (a) operational excellence, (b) managerial efficiency, (c) organizational effectiveness, and (d) firm performance.

\subsection{Competitor Orientation}

Competitor orientation plays a significant role in explaining firm performance. It refers to an ability of firms to identify their current and potential competitors, understand, monitor and respond to the strength, weakness, capabilities, and strategies of those competitors, and constantly collect competitor information from the marketplace (Bell, Lai, $\& \mathrm{Li}, 2012$ ). Firms with competitor orientation definitely seek to understand and respond to competitors' moves and capture their current and emerging strategies and technologies for creating customer value and discovering and satisfying extant and expected needs of their target markets under increasing competition and environmental turbulence. Similarly, firms attempt to identify specific self-competencies to protect their competitors by exploiting and continuously surveying and searching the markets for such threats and opportunities. They are likely to implement valuable strategies for enhancing competitive advantage and achieving firm performance. Likewise, competitor orientation outstandingly enables firms to have a great vigilance to competitors' actions and a willingness to consider those actions when deploying their resources for doing businesses successfully toward market actions (Crick, Crick, \& Tebbett, 2020).

Competitor-oriented firms tend to compare their businesses with their competitors in terms of resources, cost positions and financial performance occurs. Thus, competitor orientation can help firms understand their relative standing in the market, anticipate and respond quickly to competitors' actions and improve firm performance (Chen \& Myagmarsuren, 2013). In order for businesses to gain sustainable competitive advantage, the aforementioned information related to their competitors is provided from several sources. Strategic management accounting that is one of the best competitor information sources helps them capture competitors' actions and activities and develop distinctive competencies and differentiation in attaining sustainable competitive advantage by creating superior customer value and performance over the competitors. Therefore, 
H2: Competitor orientation positively affects operational excellence, (b) managerial efficiency, organizational effectiveness, and (d) firm performance.

\subsection{Forward-Looking Information}

Forward-looking information is defined as the disclosure of current plans and future forecasts that enable investors and other users to assess a firm's expected future financial performance. It involves financial forecasts such as next year earnings, expected revenues and anticipated cash flows and non-financial information such as risks and uncertainties that could significantly affect actual results and cause them to differ from projected results. Firms with forward-looking information can reduce the degree of information asymmetry and their costs of external financing. Also, forward-looking information is an essential factor to assist information users to better understand what a firm's previous and present performance may be in the future (Liu, 2015; Menicucci, 2018). It helps users project future performance and the quality of investment opportunities. Accordingly, forwardlooking information becomes the most popular frameworks for voluntary corporate disclosure in conveying valuerelevant information to external users (Bravo \& Dolores Alcaide-Ruiz, 2019).

However, forward-looking information may provide disadvantage disclosure if there is uncertainty associated with the future, deliberate management bias and presentation of competitive position in product markets to competitors. In the management accounting under strategic aspect, forwardinglooking information is the disclosure of both predicted future financial and non-financial information to internal users for supporting business strategies and encouraging competitive advantage and superior performance. It is essential to enhance executives to survive in business operation and make them sustainable in competitive markets. Hence, firms that have forward-looking information tend to gain operational excellence, managerial efficiency and organizational effectiveness and achieve great firm performance. Therefore,

H3: Forward-looking information positively affects (a) operational excellence, (b) managerial efficiency, (c) organizational effectiveness, and (d) firm performance.

\subsection{Operational Excellence}

Operational excellence refers to the provision of business practice quality through a management system to exceed a customer's previous expectations by bringing about customer satisfaction, customer delight and customer loyalty and leading to higher profitability (Asif \& Gouthier, 2014). It is important to help firms increase customer value, sustain competitive advantage and achieve great firm performance.
Firms with operational excellence receive continuous survival and sustainability. Likewise, operational excellence is defined as outstanding practice in managing an organization and achieving good results (Sony \& Naik, 2019). It is a constant pursuit of improved performance and profitability and leads to business success in an organization. In the uncertain environments, operational excellence is significant in creating sustainable and continuous improvement of business processes that bring strong financial performance and enhance high customer demand, goal achievement, successful employee recruitment and admission, desired products and service outcome, and outstanding staff (Yeo, 2019). It is a result of continuous process improvement under a philosophy of leadership, teamwork and problem solving in an organization via focusing on needs of customers, empowering employees and optimizing existing activities.

Hence, operational excellence definitely reflects firms' best practices that relate to business success and create their great performance. Thus, operational excellence is likely to have a positive influence on firm performance. Also, operational excellence can help link strategic management accounting to firm performance. Firms have implemented strategic management accounting in an organization in order to increase their operational excellence while the operational excellence can enhance better performance. Accordingly, operational excellence seems to become a mediator of the strategic management accounting-firm performance relationships. It mediates the environmental scanning-firm performance relationships, the competitor orientationfirm performance relationships and the forward-looking information-firm performance relationships. Therefore,

H4: Operational excellence positively affects firm performance.

H5: Operational excellence significantly mediates (a) the environmental scanning-firm performance relationships, (b) the competitor orientation-firm performance relationships and (c) the forward-looking information-firm performance relationships.

\subsection{Managerial Efficiency}

Facing highly competitive market environment, formation of marketing strategies, strengthening corporate operations and upgrading the quality of service have become essential for survival. Managerial efficiency is an important instrument for helping firms survive and sustain themselves under the environment. It is defined as a comparison between observed and optimal values of a firm's output and input. Moreover, managerial efficiency that is a result of firms' business operations and activities reflects their ability to minimize input usage under the production of given output and to maximize output production with given inputs. Firms 
with managerial efficiency have motivated their valuable customers in participating and buying products and services. Managerial efficiency is a determinant of firm performance and profitability. It could be measured in two aspects, such as difference of its actual performance and what could have been achieved under best practice decisions (Sun, 2019), and its actual performance is relative to the maximum attainable performance that would be predicted by the production frontier (Chang \& Ma, 2019).

Hence, managerial efficiency explicitly addresses the ability of firms to transform input into output and enhance them to sustain competitive advantage, receive valuable organizational success, and achieve superior firm profitability and performance. Thus, managerial efficiency is likely to have a positive influence on firm performance. Likewise, managerial efficiency becomes a mediator of the strategic management accounting-firm performance relationships. It is proposed to drive the changes of firms' performance and in the same time, it is a consequence of their strategic management accounting implementation. Hence, managerial efficiency significantly mediates the environmental scanning-firm performance relationships, the competitor orientation-firm performance relationships and the forward-looking information-firm performance relationships. Therefore,

H6: Managerial efficiency positively affects firm performance.

H7: Managerial efficiency significantly mediates (a) the environmental scanning-firm performance relationships, (b) the competitor orientation-firm performance relationships and (c) the forward-looking information-firm performance relationships.

\subsection{Organizational Effectiveness}

Organizational effectiveness is a consequence of strategic management accounting. It refers to the degree to which firms realize their goals. To compare with their competitors, organizational effectiveness positively contributes to overall success, market share, profitability, growth rate, and innovativeness. A result of organizational effectiveness directly increases competitive advantage and firm performance. Organizational effectiveness is defined as the ability of firms to meet the needs of the target audience (Ferreira \& Proenca, 2015). It derives from the ability to solve problems, implement valuable strategies, create new services, and develop new processes in order to analyze and meet customers that explicitly affect firms' great competitiveness, profitability and performance. In achieving organizational effectiveness, healthy financial organization, external confidence in the organization, efficient and reliable organizational processes, and employee's confidence in the organization have become indicators of firms' effectiveness in market competition growth (Sharma \& Singh, 2019). Likewise, organizational effectiveness is defined as how a firm accomplishes its tasks effectively. It is potential to fulfill customer requirements and create customer satisfaction through commitment, attachment and happiness. Being aware of organizational effectiveness via productivity, adaptability and flexibility, firms have provided the long-term ability to achieve consistently their strategic and operational goals.

Hence, organizational effectiveness helps them maintain internal efficiency, optimize the use of organizational resources, increase adaptability and ability to sustain themselves through the external inconsistencies, and achieve their goals and objectives. Thus, organizational effectiveness is likely to have a positive influence on firm performance. Also, organizational effectiveness is a mediator of the research relationships. When firms have an important effect of strategic management accounting on organizational effectiveness, the organizational effectiveness can improve their performance. Then, organizational effectiveness is likely to mediate the strategic management accounting-firm performance relationships. It mediates the environmental scanning-firm performance relationships, the competitor orientation-firm performance relationships and the forwardlooking information-firm performance relationships. Therefore,

H8: Organizational effectiveness positively affects firm performance.

H9: Organizational effectiveness significantly mediates (a) the environmental scanning-firm performance relationships, (b) the competitor orientation-firm performance relationships and (c) the forward-looking information-firm performance relationships.

Figure 1 displays the conceptual model of the strategic management accounting-firm performance relationships.

\section{Research Methods}

\subsection{Sample Selection and Data Collection Procedure}

All 245 finance businesses in Thailand from the Stock Exchange of Thailand and Bank of Thailand were selected as the samples of the study, including banks, insurance, investment, security, and credit foncier companies and related businesses. A mail survey procedure via questionnaire was used for data collection. The key informants were accounting executives of finance businesses in Thailand. These accounting executives have taken the highest responsibilities of accounting functions and other related activities in an organization, such as chief financial officers, accounting directors or accounting managers. All questionnaires are 


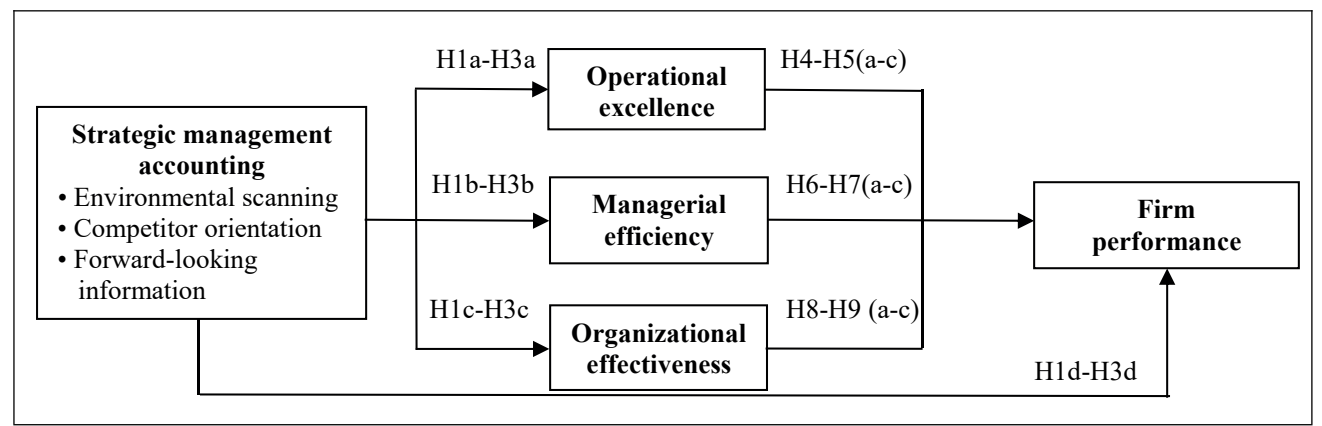

Figure 1: Conceptual model

Table 1: Demographic characteristics of financial businesses in Thailand

\begin{tabular}{|l|l|c|c|}
\hline \multicolumn{1}{|c|}{ Descriptions } & \multicolumn{1}{|c|}{ Categories } & Frequencies & Percentage \\
\hline No. of operation periods & $<15$ years & 75 & 42.86 \\
\hline & $=>15$ years & 100 & 57.14 \\
\hline No. of full-time employees & $<500$ employees & 46 & 29.26 \\
\hline & $=>500$ employees & 129 & 73.71 \\
\hline Firm capital & $<10,000$ million baht & 103 & 58.86 \\
\hline & $=>10,000$ million baht & 72 & 41.14 \\
\hline
\end{tabular}

sent to the accounting executives by clearly describing the objectives of the study, explicitly determining the dateline of questionnaire returned and systematically following up the questionnaires. With regard to the questionnaire mailing, 43 surveys were undeliverable because some listed firms had moved to unknown locations. Deducting the undeliverable from the original 245 mailed, the valid mailing was 202 surveys, from which 189 responses were received. Of the surveys completed and returned, 175 were usable. The effective response rate was approximately $86.63 \%$. According to Aaker, Kumar, and Day (2001), the response rate for a mail survey, with an appropriate followup procedure, if greater than $20 \%$ is considered acceptable.

Table 1 shows the demographic characteristics of financial businesses in Thailand in this study, including a number of operation periods, a number of full-time employees, and firm capital. The financial businesses in Thailand as more than half or 57.14 percent have done their operations for 15 years or more. Also, almost three quarters or 73.71 percent of these businesses have 500 employees or more in their organizations and more than half or 58.86 percent of the businesses engaged in a firm capital of less than 10,000 million baht.

To test potential and non-response bias and to detect and consider possible problems with non-response errors, the assessment and investigation of non-response-bias were centered on two different procedures: (1) a comparison of sample statistics and known values of the population, such as firm age and firm capital, and (2) a comparison of the first and the second wave data as recommended by Armstrong and Overton (1977). In this regard, neither procedure showed significant differences.

\subsection{Measures}

All constructs were measured using a 5-point Likert scale ( 1 = strongly disagree to $5=$ strongly agree), except for firm size, firm age, and firm capital. Sources of measurements for these constructs are self-developed from existing literatures as shown in Table 2. Appendix A presents the measurements of all variables in this study.

For the control variables, there are three variables, including firm age, firm size and firm capital. Firstly, firm age (FA) may influence a firm's technological learning capacity, implementing business activities, actions and strategies, and the profitability of organizational operations (Zahra, Ireland, $\&$ Hitt, 2000). It was measured by the number of years a firm has been in existence by using a dummy variable as less than 15 years $=0$ and equal to or greater than 15 years $=1$. Secondly, firm size (FS) may affect the ability to learn and diversify operations, and to compete and survive in the markets (Arora \& Fosfuri, 2000). It was measured by the 
Table 2: Sources of measurements for all variables

\begin{tabular}{|l|c|c|}
\hline \multicolumn{1}{|c|}{ Variables } & Items & Sources \\
\hline Firm Performance (FP) & 4 & Joni, Ahmed, and Hamilton (2019) \\
\hline Environmental Scanning (ES) & 5 & Bhardwaj and Kumar (2014) \\
\hline Competitor Orientation (CO) & 5 & Bell, Lai, and Li (2012) \\
\hline Forward-Looking Information (FI) & 5 & Menicucci (2019) \\
\hline Operational Excellence (OE) & 4 & Asif and Gouthier (2014) \\
\hline Managerial Efficiency (ME) & 4 & Chang and Ma (2019) \\
\hline Organizational Effectiveness (OF) & 4 & Ferreira and Proenca (2015) \\
\hline
\end{tabular}

Table 3: Results of measure validation

\begin{tabular}{|l|c|c|c|}
\hline \multicolumn{1}{|c|}{ Items } & Factor Loadings & Item-total Correlation & Cronbach Alpha \\
\hline Firm Performance (FP) & $0.82-0.93$ & $0.82-0.93$ & 0.91 \\
\hline Environmental Scanning (ES) & $0.52-0.83$ & $0.61-0.78$ & 0.74 \\
\hline Competitor Orientation (CO) & $0.66-0.91$ & $0.71-0.88$ & 0.84 \\
\hline Forward-Looking Information (FI) & $0.86-0.90$ & $0.68-0.83$ & 0.82 \\
\hline Operational Excellence (OE) & $0.75-0.91$ & $0.78-0.90$ & 0.88 \\
\hline Managerial Efficiency (ME) & $0.70-0.93$ & $0.70-0.92$ & 0.88 \\
\hline Organizational Effectiveness (OF) & $0.78-0.90$ & $0.78-0.89$ & 0.87 \\
\hline
\end{tabular}

number of employees in a firm by using a dummy variable as less than 500 employees $=0$ and equal to or greater than 500 employees $=1$. Lastly, firm capital $(\mathrm{FC})$ may impact the capacity of a firm to implement business methods and strategies in order to achieve competitive advantage and superior performance (Ussahawanitchakit, 2007). It was measured by the amount of money a firm has invested in doing business by using a dummy variable as less than 10,000 million baht $=0$ and equal to or greater than 10,000 million baht $=1$.

\subsection{Methods}

To manifest the validity and reliability of the questionnaire instrument, a pre-test approach was performed in order to recognize all items in each construct that can measure them. Of the surveys completed and returned, the first 30 were usable for verifying both the validity and reliability because this study used all 245 finance businesses in Thailand. As a result, factor analysis was implemented to assess the underlying relationships of a large number of items and to determine whether they can be reduced to a smaller set of factors. Factor analysis was conducted separately on each set of the items representing a particular scale due to limited observations. This analysis has a high potential to inflate the component loadings. Thus, a higher rule-of-thumb, a cut-off value of 0.40 , was adopted
(Nunnally \& Bernstein 1994). All factor loadings are greater than the 0.40 cut-off and are statistically significant. Also, discriminant power was utilized to gauge the validity of the measurements by item-total correlation. In the scale validity, item-total correlation is greater than 0.30 (Churchill, 1979). Likewise, the reliability of the measurements was evaluated by Cronbach alpha coefficients. In the scale reliability, Cronbach alpha coefficients are greater than 0.70 (Nunnally $\&$ Bernstein, 1994). The scales of all measures appear to produce internally consistent results; thus, these measures are deemed appropriate for further analysis as they express an accepted validity and reliability in this study. Table 3 presents the results for factor loadings, item-total correlation and Cronbach alpha for multiple-item scales used in this study.

The hierarchical multiple regression analysis was conducted to test the relationships among strategic management accounting (environmental scanning, competitor orientation and forward-looking information), operational excellence, managerial efficiency, organizational effectiveness, and firm performance. Because all dependent variables, independent variables, mediating variables, antecedent variables, and control variables in this study were neither nominal data nor categorical data, the hierarchical multiple regression analysis is an appropriate method for examining the hypothesized relationships (Chan \& Mak, 2012). 


\section{Results and Discussion}

Table 4: Descriptive statistics and correlation matrix

\begin{tabular}{|c|c|c|c|c|c|c|c|}
\hline Variables & $\mathrm{FP}$ & ES & $\mathrm{CO}$ & $\mathrm{FI}$ & OE & ME & OF \\
\hline Mean & 3.98 & 4.10 & 3.87 & 4.08 & 3.83 & 3.80 & 3.88 \\
\hline Standard Deviation & 0.72 & 0.36 & 0.50 & 0.38 & 0.52 & 0.63 & 0.59 \\
\hline \multicolumn{8}{|l|}{ Firm Performance (FP) } \\
\hline Environmental Scanning (ES) & $0.52^{* * *}$ & & & & & & \\
\hline Competitor Orientation (CO) & $0.39^{* *}$ & $0.43^{* * *}$ & & & & & \\
\hline Forward-Looking Information (FI) & 0.30 & 0.30 & 0.29 & & & & \\
\hline Operational Excellence (OE) & 0.22 & 0.24 & $0.31^{* *}$ & 0.25 & & & \\
\hline Managerial Efficiency (ME) & $0.57^{* * *}$ & 0.24 & $0.42^{* * *}$ & $0.42^{* * *}$ & 0.10 & & \\
\hline Organizational Effectiveness (OF) & $0.69^{* * *}$ & $0.31^{* *}$ & $0.41^{* * *}$ & $0.37^{* *}$ & 0.16 & $0.79^{* * *}$ & \\
\hline
\end{tabular}

${ }^{* *} p<.05,{ }^{* * *} p<.01$

Table 4 presents the descriptive statistics and correlation matrix for all variables. With respect to potential problems relating to multicollinearity, variance inflation factors (VIFs) were used to provide information on the extent to which nonorthogonality among independent variables inflates standard errors. The VIFs range from 1.01 to 1.84 , well below the cutoff value of 10 as recommended by Neter, Wasserman, and Kutner (1985), means that the independent variables are not correlated with each other. Therefore, there are no substantial multicollinearity problems encountered in this study.

Table 5 shows the results of hierarchical regression analysis of the relationships among strategic management accounting (environmental scanning, competitor orientation and forward-looking information), operational excellence, managerial efficiency, organizational effectiveness, and firm performance. Environmental scanning has a positive effect on operational excellence $(b=0.25, p<0.02)$, organizational effectiveness $(b=0.23, p<0.03)$ and firm performance $(b$ $=0.30, p<0.10)$. Accordingly, environmental scanning helps firms explicitly provide the gathering of information concerning a firm's external environments, the analysis and interpretation of this information and the use of this analyzed intelligence in strategic decision making (Abu-Rahma \& Jaleel, 2019). They have implemented environmental scanning to monitor, evaluate and disseminate the external environments to identify opportunities and threats and to establish critical strategies for gaining competitive advantage and receiving business success in the competitive markets. In contrast, environmental scanning has no effect on managerial efficiency $(b=0.07, p<0.43)$. It likely focuses on external information while managerial efficiency only emphasizes internal information inside the organization. Thus, environmental scanning may not benefit managerial efficiency. In brief, environmental scanning is a key driver for explaining operational excellence, organizational effectiveness and firm performance. Therefore, Hypotheses $1 \mathrm{a}, 1 \mathrm{c}$ and $1 \mathrm{~d}$ are supported, but Hypothesis $1 \mathrm{~b}$ is not.

Competitor orientation is positively related to managerial efficiency $(b=0.31, p<0.08)$ and organizational effectiveness $(\mathrm{b}=0.26, p<0.02)$. In the existing literature, competitor orientation is essential to help firms identify their current and potential competitors, understand, monitor and respond to the strength, weakness, capabilities, and strategies of those competitors, and constantly collect competitor information from the marketplace (Crick, Crick, \& Tebbett, 2020). To survive in increasing competition and environmental turbulence, firms have understood and responded to competitor moves and capture their current and emerging strategies and technologies for creating customer value and discovering and satisfying extant and expected needs of their target markets. Surprisingly, competitor orientation has no impact on operational excellence $(b=0.15, p<0.23)$ and firm performance $(b=0.10, p<0.34)$ because it explicitly integrates competitor knowledge intention. It may not help firms efficiently operate their business activities. Thus, competitor orientation definitely plays a significant role in determining both managerial efficiency and organizational effectiveness. Therefore, Hypotheses $2 b$ and $2 c$ are supported, but Hypotheses $2 \mathrm{a}$ and $2 \mathrm{~d}$ are not.

Interestingly, forward-looking information has a positive influence on operational excellence $(b=0.23, p<0.06)$, managerial efficiency $(b=0.31, p<0.10)$, organizational effectiveness $(b=0.21, p<0.07)$, and firm performance $(b$ $=0.33, p<0.07)$. Forward-looking information is a potential factor to assist information users to better understand what a firm's previous and present performance may be in the future and successfully project future firm performance and the quality of investment opportunities (Bravo \& Dolores 
Table 5: Results of hierarchical multiple regression analysis ${ }^{\mathrm{a}}$

\begin{tabular}{|l|c|c|c|c|c|c|c|c|c|c|}
\hline Independent & & \multicolumn{7}{|c|}{} & \multicolumn{7}{|c|}{ Dependent Variables } \\
\hline Variables & OE & OE & ME & ME & OF & OF & FP & FP & FP & FP \\
\hline ES & & $0.25^{\star *}$ & & 0.07 & & $0.23^{* *}$ & & $0.30^{*}$ & & \\
\hline CO & & $(0.03)$ & & $(0.19)$ & & $(0.03)$ & & $(0.17)$ & & \\
\hline & & 0.15 & & $0.31^{*}$ & & $0.26^{* *}$ & & 0.10 & & \\
\hline FI & & $(0.18)$ & & $(0.17)$ & & $(0.07)$ & & $(0.16)$ & & \\
\hline & & $0.23^{*}$ & & $0.31^{*}$ & & $0.21^{*}$ & & $0.33^{*}$ & & \\
\hline OE & & $(0.10)$ & & $(0.16)$ & & $(0.19)$ & & $(0.17)$ & & \\
\hline & & & & & & & & & & $0.33^{* * *}$ \\
\hline ME & & & & & & & & & & $(0.10)$ \\
\hline & & & & & & & & & & $0.21^{*}$ \\
\hline OF & & & & & & & & & & $(0.09)$ \\
\hline & & & & & & & & & & $(0.18)$ \\
\hline FA & 0.21 & 0.02 & 0.13 & 0.13 & 0.20 & 0.06 & -0.10 & -0.11 & -0.10 & -0.18 \\
\hline & $(0.13)$ & $(0.20)$ & $(0.14)$ & $(0.12)$ & $(0.14)$ & $(0.19)$ & $(0.14)$ & $(0.12)$ & $(0.14)$ & $(0.12)$ \\
\hline FS & 0.04 & 0.02 & 0.19 & 0.15 & 0.12 & 0.09 & -0.06 & -0.10 & -0.06 & -0.10 \\
\hline & $(0.13)$ & $(0.14)$ & $(0.13)$ & $(0.13)$ & $(0.13)$ & $(0.13)$ & $(0.13)$ & $(0.13)$ & $(0.13)$ & $(0.18)$ \\
\hline FC & 0.19 & 0.20 & 0.05 & 0.06 & 0.06 & 0.04 & 0.14 & 0.10 & 0.14 & 0.07 \\
\hline & $(0.12)$ & $(0.15)$ & $(0.12)$ & $(0.14)$ & $(0.12)$ & $(0.14)$ & $(0.13)$ & $(0.13)$ & $(0.13)$ & $(0.09)$ \\
\hline Adjusted R & 0.06 & 0.24 & 0.02 & 0.31 & 0.01 & 0.30 & 0.03 & 0.25 & 0.03 & 0.55 \\
\hline
\end{tabular}

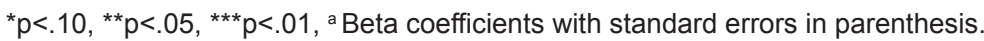

Alcaide-Ruiz, 2019). Valuable forward-looking information helps firms receive both predicted future financial and nonfinancial information in supporting their business plans and strategies and encouraging them to achieve competitive advantage and superior firm performance. Importantly, forward-looking information is a main factor of driving operational efficiency, managerial efficiency, organizational effectiveness, and firm performance. Therefore, Hypotheses 3a-3d are supported.

In addition, operational excellence has a positive influence on firm performance $(b=0.33, p<0.01)$. Besides, operational excellence is an outstanding practice in managing an organization and achieving good results (Yeo, 2019). It creates sustainable and continuous improvement of business processes that bring strong financial performance and enhances high customer demand, goal achievement, successful employee recruitment and admission, desired product and service outcomes, and outstanding staff. Thus, operational efficiency tends to enhance firms to gain great performance in the competitive markets. Therefore, Hypothesis 4 is supported.

Managerial efficiency positively affects firms' strong performance $(b=0.21, p<0.09)$. It is a result of firms' business operations and activities that reflect their ability to minimize input usage under the production of given output and to maximize output production with given input (Chang \& Ma, 2019). Also, managerial efficiency that explicitly motivates firms' valuable customers in participating and buying products and services is a determinant of firm performance and profitability. Hence, managerial efficiency encourages firms to successfully do business practices in achieving high firm performance. Therefore, Hypothesis 6 is supported.

Lastly, organizational effectiveness positively influences firms' high performance $(\mathrm{b}=0.68, p<0.01)$. It is the ability of firms to solve problems, implement valuable strategies, create new services and develop new processes in order to analyze and meet customers that explicitly affect their great competitiveness, profitability and performance (Ferreira \& Proenca, 2015). Firms show potential to have healthy financial organization, external confidence in the organization, efficient and reliable organizational processes, and employee's confidence in the organization. Hence, organizational effectiveness is potential to fulfill customer requirements, and create customer satisfaction through 
commitment, attachment and happiness and results in great performance. Therefore, Hypothesis 8 is supported.

For verifying the mediating effects of this study according to Baron and Kenny (1986), operational excellence firstly has a significant effect on firm performance $(b=0.33, p<$ 0.01 ) while it is an important consequence of environmental scanning $(\mathrm{b}=0.25, p<0.02)$. Similarly, operational excellence is the dependent variable of forward-looking information $(b=0.23, p<0.06)$ and in the same time, it is the independent variable of firm performance $(b=0.33, p<$ $0.01)$. As mentioned earlier, operational excellence explicitly makes a critical function of this study that can link both environmental scanning and forward-looking information to firm performance. Also, environmental scanning and forward-looking information have indirect impacts on firm performance $(b=0.30, p<0.10 ; b=0.33, p<0.07)$ respectively. Thus, operational excellence is the partial mediator of the environmental scanning-firm performance relationships and the forward-looking information-firm performance relationships. Therefore, Hypotheses 5a and 5c are supported.

Secondly, managerial efficiency significantly mediates the competitor orientation-firm performance relationships and the forward-looking information-firm performance relationships. Firms with great competitor orientation are likely to have a superior managerial efficiency and they also have a positive influence of managerial efficiency on firm performance. Then, both competitor orientation and forwardlooking information can lead to managerial efficiency $(\mathrm{b}=0.31, p<0.08 ; \mathrm{b}=0.31, p<0.10)$ and managerial efficiency explicitly impact firm performance $(b=0.21, p$ $<0.09$ ). Likewise, forward-looking information can directly affect firm performance $(b=0.33, p<0.07)$. Accordingly, managerial efficiency is the full mediator of the competitor orientation-firm performance relationships and the partial mediator of forward-looking information-firm performance relationships (Baron \& Kenny, 1986). Therefore, Hypotheses $7 \mathrm{~b}$ and $7 \mathrm{c}$ are supported.

Thirdly, environmental scanning, competitor orientation and forward-looking information have an important relationship with organizational effectiveness $(b=0.23$, $p<0.03 ; \mathrm{b}=0.26, p<0.02 ; \mathrm{b}=0.21, p<0.07)$. Also, organizational effectiveness has a significant effect on firm performance $(b=0.68, p<0.01)$. Both environmental scanning and forward-looking information can indirectly lead to firm performance $(\mathrm{b}=0.30, p<0.10 ; \mathrm{b}=0.33, p<$ $0.07)$ respectively. Hence, organizational effectiveness is the full mediator of the competitor orientation-firm performance relationships and the partial mediator of the environmental scanning-firm performance relationships and the forwardlooking information-firm performance relationships. Therefore, Hypotheses 9a-9c are supported.

\section{Contributions and Directions for Future Research}

\subsection{Theoretical Contribution and Directions for Future Research}

This study is an attempt to investigate the strategic management accounting-firm performance relationships. Strategic management accounting definitely plays the significant roles in determining business outcomes. Congruence with the study of Barney (1991), environmental scanning, competitor orientation and forward-looking information become valuable sources of firm performance. The results verify the theory and prior studies of strategic management accounting implementation. This study also expands the existing literature by integrating environmental scanning, competitor orientation and forward-looking information in the same model while a few studies has attempted to study and understand this model. To expand the contributions of the study, future research is needed to test the generalizability of the study by collecting data from different populations and countries and using a comparative study to test the research relationships. Likewise, future research may provide more literature review relating to environmental scanning and competitor orientation in order to make the high level of reliable results because some studies attempt to examine those constructs in marketing aspect, not in management accounting aspect.

\subsection{Managerial Contribution}

This study helps firms identify key components that are more critical in a rigorously strategic management accounting. Strategic management accounting is a key driver in determining firm performance. It consists of environmental scanning, competitor orientation and forward-looking information. Firms can apply strategic management accounting in an organization as a strategic mechanism for creating competitiveness in order to achieve better performance and to survive and sustain in business operations under rigorously competitive environments. Accordingly, the executives of firms need to provide strategic management accounting through environmental scanning, competitor orientation and forward-looking information in order to achieve operational excellence, managerial efficiency, organizational effectiveness, and firm performance. That is, they may put more emphasis on the aforementioned concepts than on other variations. To maximize the benefits of firm performance, these executives need to furnish how firms utilize those dimensions of strategic management accounting, especially forward-looking information, and create new opportunities and sustainability in the competitive environments. 


\section{Conclusion}

In the rigorous environments, valuable strategy has become a significant tool that helps firms survive and sustain. In this study, strategic management accounting is a driver of determining firm performance in those environments. This study attempts to examine the relationships among strategic management accounting, operational excellence, managerial efficiency, organizational effectiveness, and firm performance. To obtain data, the 175 finance businesses in Thailand are the samples of the study. Firstly, environmental scanning positively affects operational excellence, organizational effectiveness and firm performance; competitor orientation is positively related to managerial efficiency and organizational effectiveness; and forward-looking information has a positive influence on operational excellence, managerial efficiency, organizational effectiveness, and firm performance. Secondly, operational excellence, managerial efficiency and organizational effectiveness have a positive effect on firm performance. Lastly, operational excellence, managerial efficiency and organizational effectiveness are the mediators of the research relationships. To increase the benefits of the study, future research is needed to investigate the generalizability of the study by collecting data from different populations and countries and provide more literature review relating to environmental scanning and competitor orientation in order to make the high level of the reliable results. In addition, executives need to pay more attention to strategic management accounting. They may implement it to gain operational excellence, managerial efficiency, organizational effectiveness, and firm performance. In summary, they need to utilize forward-looking information productively and review more literature on environmental scanning and competitor orientation and implement them efficiently in order to achieve superior business outcome in the competitive environments.

\section{References}

Aaker, D. A., Kumar, V., \& Day, G. S. (2001). Marketing research. New York, NY: John Wiley and Sons.

Aaltola, P. (2019). Strategic thinking and accounting: potentials and pitfalls from a managerial perspective. Journal of Management Control, 30, 323-351.

Abu-Rahma, A., \& Jaleel, B. (2019). Perceived uncertainty and use of environmental information in decision making: the case of the United Arab Emirates. Journal of Organizational Analysis, 27(3), 690-711.

Armstrong, J. S, \& Overton, T. S. (1977). Estimating non-response bias in mail surveys. Journal of Marketing Research, 14(3), 396-402.
Arora, A., \& Fosfuri, A. (2000). Wholly owned subsidiary versus technology licensing in the worldwide chemical industry. Journal of International Business Studies, 31(4), 555-572.

Asif, M., \& Gouthier, M. H. J. (2014). What service excellence can learn from business models. Total Quality Management and Business Excellence, 25(5-6), 511-531.

Barney, J. B. (1991). Firm resources and sustained competitive advantage. Journal of Management, 17(1), 99-120.

Barney, J. B. (2001). Resource-based theories of competitive advantage: a ten year retrospective on the resource-based view. Journal of Management, 27(6), 643-650.

Baron, R. M., \& Kenny, D. A. (1986). The moderator-mediator variable distinction in social psychological research: conceptual, strategic, and statistical considerations. Journal of Personality and Social Psychology, 51, 1173-1182.

Bell, G., Lai, F., \& Li, D. (2012). Firm orientation, community of practice, and internet-enabled interfirm communication: evidence from Chinese firms. Journal of Strategic Information Management, 21, 201-215.

Bhardwaj, S. S., \& Kumar, D. (2014). Environmental scanning of FMCG companies in India: a comparative study. International Journal of Management and International Business Studies, 4(1), 39-50.

Bravo, F., \& Dolores Alcaide-Ruiz, M. (2019). The disclosure of financial forward-looking information: does the financial expertise of female directors make a difference. Gender in Management, 34(2), 140-156.

Cadez, S., \& Guilding, C. (2008). An exploratory investigation of an integrated contingency model of strategic management accounting. Accounting, Organizations, and Society, 33, 836863.

Chan, S. C. H., \& Mak, W. (2012). Benevolent leadership and follower performance: the mediating role of leader-member exchange (LMX). Asia-Pacific Journal of Management, 29, 285-301.

Chang, H., \& Ma, C. (2019). Financial flexibility, managerial efficiency and firm life cycle on firm performance: an empirical analysis of Chinese listed firms. Journal of Advances in Management Research, 16(2), 168-180.

Chen, C. (2007). Applying the stochastic frontier approach to measure hotel managerial efficiency in Taiwan. Tourism Management, 28, 696-702.

Chen, C., \& Myagmarsuren, O. (2013). Exploring the moderating effects of value offerings between market orientation and performance in tourism industry. International Journal of Tourism Research, 15, 595-610.

Cheng, T. Y., Li, Y., Lin, Y., \& Chih, H. (2020). Does the fit of managerial ability with firm strategy matters on firm performance. Journal of Asian Finance, Economics, and Business, 7(4), 9-19. https://doi.org/10.13106/jafeb.2020.vol7. no4.9 
Churchill, G. A., Jr. (1979). A paradigm for developing better measures of marketing constructs. Journal of Marketing Research, 16(February), 64-73.

Crick, J. M., Crick, D., \& Tebbett, N. (2020). Competitor orientation and value co-creation in sustaining rural New Zealand wine products. Journal of Rural Studies, 73, 122-134.

Ferreira, M. R., \& Proenca, J. F. (2015). Strategic planning and organizational effectiveness in social service organizations in Portugal. Management, 20(2), 1-21.

Joni, J., Ahmed, K., \& Hamilton, J. (2019). Politically connected boards, family business groups and firm performance: evidence from Indonesia. Journal of Accounting and Organizational Change, 16(1), 93-121.

Lachmann, M., Knauer, T., \& Trapp, R. (2013). Strategic management accounting practices in hospitals: empirical evidence on their dissemination under competitive market environments. Journal of Accounting and Organizational Change, 9(3), 336-369.

Liu, S. (2015). Corporate governance and forward-looking disclosure: evidence from China. Journal of International Accounting, Auditing and Taxation, 25, 16-30.

Menicucci, E. (2018). Exploring forward-looking information in integrated reporting: a multi-dimensional analysis. Journal of Applied Accounting Research, 19(1), 102-121.

Neter, J., Wasserman, W., \& Kutner, M. H. (1985). Applied linear statistical models: regression, analysis of variance, and experimental designs $\left(2^{\text {nd }}\right.$ ed.). Homewood, IL: Richard D. Irwin.

Nguyen, H. T., \& Nguyen, A. H. (2020). The impact of capital structure on firm performance: evidence from Vietnam. Journal of Asian Finance, Economics, and Business, 7(4), 97-105. https://doi.org/10.13106/jafeb.2020.vol7.no4.97

Nunnally, J. C., \& Bernstein, I. H. (1994). Psychometric theory. New York, NY: McGraw-Hill.
Oboh, C. S., \& Ajibolade, S. O. (2017). Strategic management accounting and decision making: a survey of the Nigerian banks. Future Business Journal, 3, 119-137.

Pasch, T. (2019). Strategy and innovation: the mediating role of management and management accounting systems' use. Journal of Management Control, 30, 213-246.

Sharma, N., \& Singh, R. K. (2019). A unified model of organizational effectiveness. Journal of Organizational Effectiveness: People and Performance, 6(2), 114-128.

Sony, M., \& Naik, S. (2019). Six Sigma with C-K theory for innovations in operational excellence: a case study. Benchmarking: An International Journal, 26(7), 2105-2121.

Sun, L. (2019). Environmental efficiency, firm efficiency, and managerial ability. Advances in Public Interest Accounting, 21, 105-138.

Truong, D. D., Nguyen, H., \& Duong, T. Q. L. (2020). Factors influencing balanced scorecard application in evaluating the performance of tourist firms. Journal of Asian Finance, Economics, and Business, 7(5), 217-224. https://doi. org/10.13106/jafeb.2020.vol7.no5.217

Ussahawanitchakit, P. (2007). The influences of management capability on export performance of leather businesses in Thailand. Review of Business Research, 7(5), 1-10.

Yeo, R. K. (2019). From operational excellence to organizational significance: setting the tempo for change. Strategic Human Resource Review, 18(4), 142-149.

Yu, W., Chavez, R., Jacobs, M., Yew Wong, C., \& Yuan, C. (2019). Environmental scanning, supply chain integration, responsiveness, and operational performance: an integrative framework from an organizational information processing theory perspective. International Journal of Operations and Production Management, 39(5), 787-814.

Zahra, S. A., Ireland, R. D., \& Hitt, M. A. (2000). International expansion by new venture firms: international diversity, mode of market entry, technological learning, and performance. Academy of Management Journal, 43(5), 925-950. 


\section{Appendix A: Measurement of all variables}

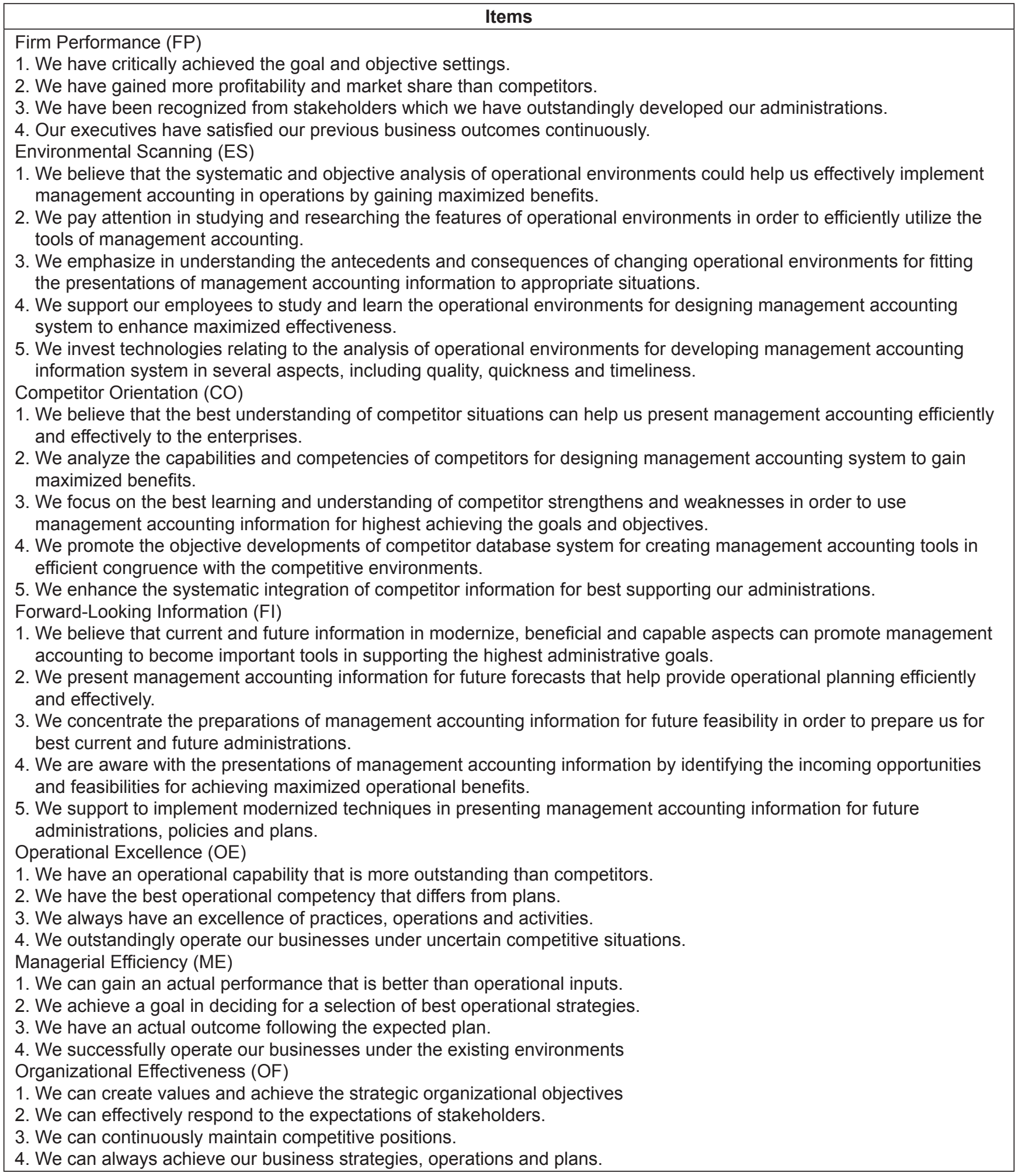

